\title{
Reaction of Alkynes with Iodine Monochloride Revisited
}

Fabio Bellina, ${ }^{*}{ }^{\dagger}$ Francesca Colzi, Luisa Mannina, ${ }^{\dagger},{ }^{\dagger}$ Renzo Rossi, ${ }^{\dagger}$ and Stéphane Viel $^{\S}$

\section{SUPPORTING INFORMATION}

$\begin{array}{ll}\text { General methods } & \text { S2 } \\ \text { Experimental details } & \text { S2-S8 } \\ \text { Table 1-3 } & \text { S-8-S9 } \\ \text { References } & \text { S9 }\end{array}$




\section{Experimental Section}

\section{General Methods}

Precoated Merck $60 \mathrm{~F}_{254}$ aluminum silica gel sheets were used for TLC analyses. GLC analyses were performed using two types of capillary columns: an Alltech AT-35 bonded FSOT column $(30 \mathrm{~m} \times 0.25 \mathrm{~mm}$ i.d.) and an Alltech AT-1 bonded FSOT column $(30 \mathrm{~m} \times 0.25 \mathrm{~mm}$ i.d). Purifications by MPLC were performed using silica gel Merck 60 (particle size $0.015-0.040 \mathrm{~mm}$ ). NMR spectra were recorded at room temperature. The ${ }^{1} \mathrm{H}$ NMR spectra were referenced to the residual $\mathrm{CHCl}_{3}$ proton of $\mathrm{CDCl}_{3}$ at $7.260 \mathrm{ppm}$ downfield of TMS and the ${ }^{13} \mathrm{C} \mathrm{NMR}$ spectra were referenced to the central line of the triplet at $77.02 \mathrm{ppm}$ for $\mathrm{CDCl}_{3}$. The structures of compounds 2a-d and 3a-e were assigned on the basis of their ${ }^{1} \mathrm{H}$ and ${ }^{13} \mathrm{C}$ NMR spectra recorded at 600 and $150 \mathrm{MHz}$, respectively, in $\mathrm{CDCl}_{3}$ solution and by a combination of 2D NMR techniques which included ${ }^{1} \mathrm{H}_{-}{ }^{13} \mathrm{C}$ HSQC (Heteronuclear Single Quantum Coherence) and ${ }^{1} \mathrm{H}-{ }^{13} \mathrm{C} \mathrm{HMBC}$ (Heteronuclear Multiple Bond Correlation). The structure and stereochemistry of compounds $(E)$ 5a-d, $(E)-6$ and $(Z)$-7a-e were assigned on the basis of their ${ }^{1} \mathrm{H}$ and ${ }^{13} \mathrm{C}$ NMR spectra recorded at 600 and $150 \mathrm{MHz}$, respectively, in $\mathrm{CDCl}_{3}$ solution and by a combination of 2D NMR techniques which included ${ }^{1} \mathrm{H}-{ }^{1} \mathrm{H}$ COSY, ${ }^{1} \mathrm{H}-{ }^{1} \mathrm{H}$ NOESY (mixing time: $400 \mathrm{~ms}$ ), ${ }^{1} \mathrm{H}-{ }^{13} \mathrm{C}$ HSQC and ${ }^{1} \mathrm{H}-{ }^{13} \mathrm{C}$ HMBC. All reactions of air- and water sensitive materials were performed in flame-dried glassware under argon, by standard syringe, cannula and septa techniques. The following compounds were prepared by published procedures: 6-undecyn-5-ol (2d) ${ }^{2}$ and 1-phenyl-1-heptyn3-ol (3a) ${ }^{3}$. 2-Butyn-1-ol (2a), propargyl alcohol (4) and 1-phenyl-1-propyne (3g) were commercially available.

\section{Experimental details}

Methyl (but-2-ynyloxy)acetate (2b). A $60 \%$ dispersion of $\mathrm{NaH}$ in mineral oil $(2.52 \mathrm{~g}, 63.4$ mmol) was washed with pentane $(2 \times 30 \mathrm{~mL})$ under an argon atmosphere and the residue was diluted with THF (40 mL). A solution of 2-butyn-1-ol (3a) (3.16 mL, $42.25 \mathrm{mmol})$ in THF (10 $\mathrm{mL}$ ) was then added dropwise during $10 \mathrm{~min}$ and the resulting mixture was stirred at room temperature. After evolution of hydrogen had ceased a solution of methyl iodoacetate $(10.1 \mathrm{~g}$, $50.7 \mathrm{mmol})$ in THF $(20 \mathrm{~mL})$ was added dropwise during $0.5 \mathrm{~h}$ and the resulting mixture was stirred at room temperature for $66 \mathrm{~h}$ and then concentrated at room temperature under reduced pressure (200 mbar). The residue was diluted with water $(50 \mathrm{~mL})$ and extracted with $\mathrm{Et}_{2} \mathrm{O}(3 \times 40$ $\mathrm{mL})$. The organic extract was dried over $\mathrm{Na}_{2} \mathrm{SO}_{4}$ and fractionally distilled to give $\mathbf{2 b}(3.74 \mathrm{~g}, 56 \%$ yield) as a colourless liquid. Bp 115-117 ${ }^{\circ} \mathrm{C} / 100$ mbar. EI-MS: $m / z$ (\%) 127 (4), 83 (25), 82 (11), 74 (100), 54 (87). IR (neat): v 2220, 1754, 1438, 1383, 1356, 1213, 1140, 1115, $915 \mathrm{~cm}^{-1} .{ }^{1} \mathrm{H}$ NMR (600 MHz, $\left.\mathrm{CDCl}_{3}\right): \delta 1.86\left(3 \mathrm{H}, \mathrm{t}, J=2.6 \mathrm{~Hz}, \mathrm{H}-4\right.$ ') $3.77\left(3 \mathrm{H}, \mathrm{s}, \mathrm{OCH}_{3}\right), 4.20(2 \mathrm{H}, \mathrm{s}, \mathrm{H}-$ 2), $4.26 \mathrm{ppm}\left(2 \mathrm{H}, \mathrm{m}, \mathrm{H}-1^{\prime}\right) .{ }^{13} \mathrm{C} \mathrm{NMR}\left(150 \mathrm{MHz}, \mathrm{CDCl}_{3}\right)$ : $\delta 3.6\left(\mathrm{C}-4\right.$ '), $51.9\left(\mathrm{OCH}_{3}\right), 58.9\left(\mathrm{C}-1^{\prime}\right)$, 66.0 (C-2), 73.8 (C-2'), 83.8 (C-3'), 170.4 ppm (C-1). Anal. Calcd. for $\mathrm{C}_{7} \mathrm{H}_{10} \mathrm{O}_{4}$ : C, 53.16; H, 6,37; Found: C, 53.07; H, 6.25 .

Methyl (1-butylhept-2-ynyloxy)acetate (2c). This compound, which was purified by MPLC on silica gel with a mixture of petroleum ether and $\mathrm{Et}_{2} \mathrm{O}(95: 5)$ as eluent, was prepared in $67 \%$ yield starting from methyl iodoacetate and 6-undecyn-5-ol (2d) according to the same procedure employed for the synthesis of $\mathbf{2 b}$. Compound $\mathbf{2 c}$ was a pale yellow liquid. EI-MS: $m / z$ (\%) 198 (10), 183 (57), 167 (26), 125 (59), 41 (100). IR (neat): v 2235, 1758, 1743, 1621, 1466, 1436, 1207, 1130, $987 \mathrm{~cm}^{-1} .{ }^{1} \mathrm{H} \mathrm{NMR}\left(600 \mathrm{MHz}, \mathrm{CDCl}_{3}\right): \delta 0.87(3 \mathrm{H}, \mathrm{t}, J=7.2 \mathrm{~Hz}, \mathrm{H}-1$ '), $0.87(3 \mathrm{H}, \mathrm{t}$, $\left.J=7.2 \mathrm{~Hz}, \mathrm{H}-11^{\prime}\right), 1.30$ (2 H, m, H-2'), 1.35 (2 H, m, H-10'), 1.39 (2 H, m, H-3'), 1.43 (2 H, m, H-9'), 1.66 (1 H, m, H-4'), 1.72 (1 H, m, H-4'), 2.17 (2 H, m, H-8'), 3.70 (3 H, s, OCH ${ }_{3}$, 4.17 (1 
$\mathrm{H}, \mathrm{m}, \mathrm{H}-2), 4.18\left(1 \mathrm{H}, \mathrm{t}, J=6.5 \mathrm{~Hz}, \mathrm{H}-5\right.$ ') $4.21 \mathrm{ppm}(1 \mathrm{H}, \mathrm{m}, \mathrm{H}-2) .{ }^{13} \mathrm{C} \mathrm{NMR}(150 \mathrm{MHz}$, $\left.\mathrm{CDCl}_{3}\right): \delta 13.4\left(\mathrm{C}-11^{\prime}\right), 13.9\left(\mathrm{C}^{\prime} 1^{\prime}\right), 18.2\left(\mathrm{C}-8^{\prime}\right), 21.8\left(\mathrm{C}-10^{\prime}\right), 22.3$ (C-2'), 27.3 (C-3'), $30.6(\mathrm{C}-$ 9'), 35.5 (C-4'), $51.6\left(\mathrm{OCH}_{3}\right), 65.1$ (C-2), 70.2 (C-5'), 77.9 (C-6'), 87.3 (C-7'), 170.9 ppm (C-1). Anal. Calcd. for $\mathrm{C}_{14} \mathrm{H}_{24} \mathrm{O}_{3}$ : C, 69.96; H, 10.06. Found: C, 69.89; H, 10.00.

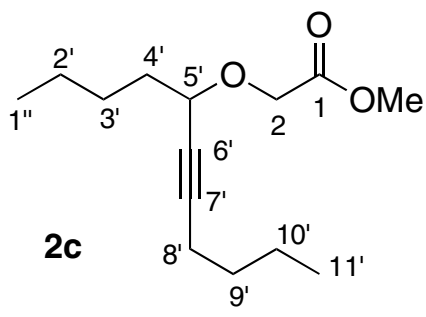

Methyl (1-butyl-3-phenylprop-2-ynyloxy)acetate (3b). This compound, which was purified by MPLC on silica gel with a mixture of hexane and $\mathrm{Et}_{2} \mathrm{O}(95: 5)$, as eluent was prepared in $60 \%$ yield from 1-phenyl-1-heptyn-3-ol (3a) and methyl iodoacetate according to the same procedure used for the synthesis of $\mathbf{2 b}$. Compound 3b was a pale yellow liquid. EI-MS: $m / z$ (\%) 203 (15), 187 (53), 145 (100), 128 (42), 115 (68). IR (neat): $v$ 2226, 1755, 1490, 1441, 1284, 1210, 1120, 757, $691 \mathrm{~cm}^{-1} .{ }^{1} \mathrm{H}$ NMR (600 MHz, $\mathrm{CDCl}_{3}$ ): $\delta 0.93(3 \mathrm{H}, \mathrm{t}, J=7.2 \mathrm{~Hz}, \mathrm{H}-7$ ') $1.30(1 \mathrm{H}, \mathrm{m}, \mathrm{H}-2)$, 1.39 (2 H, m, H-6'), 1.53 (2 H, m, H-5'), 1.84 (1 H, m, H-4'), 1.90 (1 H, m, H-4'), 3.74 (3 H, s, $\left.\mathrm{OCH}_{3}\right), 4.33(1 \mathrm{H}, \mathrm{m}, \mathrm{H}-2), 4.33(1 \mathrm{H}, \mathrm{m}, \mathrm{H}-2), 4.48(1 \mathrm{H}, \mathrm{t}, J=6.7 \mathrm{~Hz}, \mathrm{H}-3$ ') 7.29 (1 H, m, H4"), 7.31 (2 H, m, H-3" and H-5"), $7.42 \mathrm{ppm}\left(2 \mathrm{H}, \mathrm{m}, \mathrm{H}-2\right.$ " and H-6"). ${ }^{13} \mathrm{C}$ NMR (150 MHz, $\mathrm{CDCl}_{3}$ ): $\delta 13.9$ (C-7'), $22.3\left(\mathrm{C}-6^{\prime}\right), 27.3\left(\mathrm{C}^{\prime} 5^{\prime}\right), 35.3$ (C-4'), $51.7\left(\mathrm{OCH}_{3}\right), 65.4(\mathrm{C}-2), 70.5\left(\mathrm{C}-3{ }^{\prime}\right)$, 86.6 (C-1'), 87.0 (C-2'), 122.4 (C-1"), 128.2 (C-3" and C-5”), 128.4 (C-4”), 131.7 (C-2" and C6”), 170.8 ppm (C-1). Anal. Calcd. for $\mathrm{C}_{16} \mathrm{H}_{20} \mathrm{O}_{3}:$ C, 73.81; H, 7.74. Found: C, 73.69; H, 7.68.

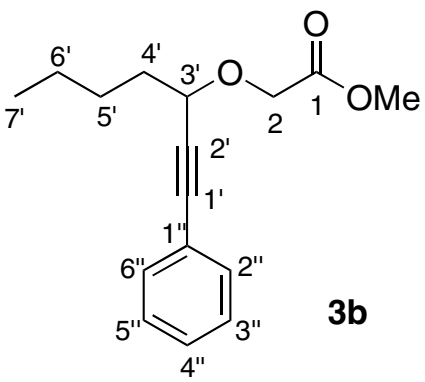

Methyl 6-phenylhex-5-ynoate (3c). A stirred solution of 5-hexynoic acid (5.22 g, $46.55 \mathrm{mmol})$ and $p$-toluenesulfonic acid $(0.58 \mathrm{~g}, 0.30 \mathrm{mmol})$ in methanol $(8.5 \mathrm{~mL})$ and $\mathrm{CH}_{2} \mathrm{Cl}_{2}(17 \mathrm{~mL})$ was refluxed for $26 \mathrm{~h}$. The mixture was then cooled to $20^{\circ} \mathrm{C}$ and a $10 \%$ aqueous $\mathrm{NaHCO}_{3}$ solution $(40 \mathrm{~mL})$ was added and the resulting mixture was extracted with $\mathrm{Et}_{2} \mathrm{O}(4 \times 50 \mathrm{~mL})$. The organic extract was dried over $\mathrm{Na}_{2} \mathrm{SO}_{4}$ and fractionally distilled to give methyl 5-hexynoate $(4.64 \mathrm{~g}, 79 \%$ yield) as a colourless liquid. Bp 104-106 ${ }^{\circ} \mathrm{C} / 130$ mbar (bp 98-100/70 mm Hg). ${ }^{4}$ Deaerated iodobenzene $(6.41 \mathrm{~g}, 31.43 \mathrm{mmol})$ and a deaerated solution of methyl 5-hexynoate $(4.65 \mathrm{~g}, 34.57$ mmol) in acetonitrile $(5 \mathrm{~mL})$ were sequentially added to a deaerated mixture of $\mathrm{PdCl}_{2}\left(\mathrm{PPh}_{3}\right)_{2}(0.47$ $\mathrm{g}, 0.67 \mathrm{mmol}), \mathrm{CuI} 80.25 \mathrm{~g}, 1.34 \mathrm{mmol})$ and $\mathrm{Et}_{3} \mathrm{~N}(14 \mathrm{~mL})$ in acetonitrile $(9 \mathrm{~mL})$ and the resulting mixture was stirred at room temperature for $1.5 \mathrm{~h}$. It was the treated with a saturated aqueous $\mathrm{NH}_{4} \mathrm{Cl}$ solution $(80 \mathrm{~mL})$ and extracted with AcOEt $(4 \times 60 \mathrm{~mL})$. The organic extract was dried over $\mathrm{Na}_{2} \mathrm{SO}_{4}$, filtered through Celite and concentrated under reduced pressure. The residue was fractionally distilled to give 3c $\left(5.32 \mathrm{~g}, 79 \%\right.$ yield) as an orange liquid. Bp $97-98{ }^{\circ} \mathrm{C} / 0.1 \mathrm{mbar}$. EI-MS: $m / z$ (\%) 202 (12), 143 (16), 141 (11), 128 (100), 115 (49). IR (neat): $v$ 2230, 1737, 1598, 1490, 1438, 1222, 1161, 758, $693 \mathrm{~cm}^{-1} .{ }^{1} \mathrm{H}$ NMR (600 MHz, $\left.\mathrm{CDCl}_{3}\right): \delta 1.94(2 \mathrm{H}, \mathrm{m}, \mathrm{H}-3), 2.49$ (2 $\mathrm{H}, \mathrm{m}, \mathrm{H}-4), 2.52$ (2 H, m, H-2), 3.69 (3 H, s, $\left.\mathrm{OCH}_{3}\right), 7.27$ (2 H, m H-3' and H-5'), 7.29 (1 H, m, H-4'), 7.39 ppm (2 H, m, H-2' and H-6'). $\left.{ }^{13} \mathrm{C} \mathrm{NMR} \mathrm{(150} \mathrm{MHz,} \mathrm{CDCl}_{3}\right)$ : $\delta 18.9$ (C-4), $23.9(\mathrm{C}-3)$, 32.9 (C-2), $51.6\left(\mathrm{OCH}_{3}\right), 81.47$ (C-6), 88.8 (C-5), 123.8 (C-1'), 127.7 (C-4'), 128.2 (C-3' and C- 
5'), 131.6 (C-2' and C-6'), 173.7 ppm (C-1). Anal. Calcd. for $\mathrm{C}_{13} \mathrm{H}_{14} \mathrm{O}_{2}$ : C, 78.48; H, 6.59: Found: C, $78.37 ; \mathrm{H}, 6.48$.

1-Phenyl-1-octyne (3d). To a deaerated mixture of iodobenzene (8.99 g, $44.06 \mathrm{mmol})$ and $\mathrm{Pd}\left(\mathrm{PPh}_{3}\right)_{4}(1.53 \mathrm{~g}, 1.32 \mathrm{mmol})$ in pyrrolidine $(130 \mathrm{~mL})$, which was stirred at room temperature under an argon atmosphere, was added 1-octyne $(9.71 \mathrm{~g}, 88.11 \mathrm{mmol})$. After stirring at room temperature for $1.5 \mathrm{~h}$ the mixture was treated with a saturated aqueous $\mathrm{NH}_{4} \mathrm{Cl}$ solution $(300 \mathrm{~mL})$ and extracted with $\mathrm{Et}_{2} \mathrm{O}(5 \times 70 \mathrm{~mL})$. The organic extract was washed with cold $5 \%$ sulfuric acid $(3 \times 30 \mathrm{~mL})$ and water $(50 \mathrm{~mL})$, dried over $\mathrm{Na}_{2} \mathrm{SO}_{4}$ and filtered through Celite. The filtrate was concentrated under reduced pressure and the residue was fractionally distilled to give $\mathbf{5 d}$ (7.70 g, $94 \%$ yield) as a pale yellow liquid. The spectral properties of this compound were in agreement with those previously reported. ${ }^{5}$

1-(1-Butyl-3-phenylprop-2-ynyloxy)-1-butane (3e). A $60 \%$ dispersion of $\mathrm{NaH}$ in mineral oil $(0.63 \mathrm{~g}, 14.51 \mathrm{mmol})$ was washed with pentane $(2 \times 30 \mathrm{~mL})$ under an argon atmosphere and to the residue was added in one portion a solution of 1-phenyl-1-heptyn-3-ol (3a) $81.82 \mathrm{~g}$, $9.67 \mathrm{mmol}$ ) in triglyme $(14 \mathrm{~mL})$. After evolution of hydrogen had ceased, a solution of iodobutane $82.13 \mathrm{~g}, 12.76$ mmol) in triglyme $(5 \mathrm{~mL})$ was added dropwise during $15 \mathrm{~min}$. After stirring the mixture at room temperature for $64 \mathrm{~h}$, water $(120 \mathrm{~mL})$ was added and the mixture was extracted with $\mathrm{Et}_{2} \mathrm{O}(4 \times 50$ $\mathrm{mL})$. The organic extract was dried over $\mathrm{Na}_{2} \mathrm{SO}_{4}$ and concentrated under reduced pressure. The residue was purified by MPLC on silica gel with a mixture of hexane and $\mathrm{Et}_{2} \mathrm{O}(99: 1)$ as eluent to give 3e (0.73 g, $31 \%$ yield) as a colourless liquid. EI-MS: $m / z(\%) 244\left(\mathrm{M}^{+}, 1\right), 187(49), 131$ (100), 129 (13), 103 (10). IR (neat): v 1598, 1490, 1465, 1336, 1258, 1119, 1094, 756, 691 cm. ${ }^{1} \mathrm{H}$ NMR (600 MHz, CDCl $)$ ) $\delta 0.94(3 \mathrm{H}, \mathrm{t}, J=7.3 \mathrm{~Hz}, \mathrm{H}-4$ ') 0.95 (3 H, t, $J=7.5 \mathrm{~Hz}, \mathrm{H}-4$ '), 1.37 (2 H, m, H-3'), 1.43 (2 H, m, H-3"), 1.50 (2 H, m, H-2'), 1.61 (2 H, m, H-2"), 1.78 (1 H, m, H-1'), $1.83(1 \mathrm{H}, \mathrm{m}, \mathrm{H}-1$ '), $3.44(1 \mathrm{H}, \mathrm{dt}, J=9.2$ and $6.6 \mathrm{~Hz}, \mathrm{H}-1$ '”), $3.81(1 \mathrm{H}, \mathrm{dt}, J=9.2$ and $6.6 \mathrm{~Hz}, \mathrm{H}-$ 1"), 4.22 (1 H, t, $J=6.7 \mathrm{~Hz}, \mathrm{H}-1), 7.30$ (3 H, m, H-3"', H-4"' and H-5"'), 7.44 ppm (2 H, m, H2"' and H-6"'). ${ }^{13} \mathrm{C}$ NMR (150 MHz, $\mathrm{CDCl}_{3}$ ): $\delta 13.9$ (C-4"), 14.0 (C-4'), 19.4 (C-3"), 22.5 (C-3'), 27.6 (C-2'), 31.8 (C-2”), 35.7 (C-1'), 68.7 (C-1”), (C-1), 85.2 (C-3), 89.0 (C-2), 123.1 (C-1'”), 128.1 (C-4"”), 128.2 (C-3"' and C-5"'), 131.7 ppm (C-2"' and C-6"'). Anal. Calcd. for $\mathrm{C}_{17} \mathrm{H}_{24} \mathrm{O}$ : C, 83.55; H, 9.90. Found: C, 83.47; H, 9.79.

Methyl 5-phenyl-4-pentynoate (3f). A stirred solution of 4-pentynoic acid (5.00 g, $58.90 \mathrm{mmol})$, p-toluenesulfonic acid $(0.074 \mathrm{~g}, 0.39 \mathrm{mmol})$ in methanol $(10.4 \mathrm{~mL})$ and $\mathrm{CH}_{2} \mathrm{Cl}_{2}(22 \mathrm{~mL})$ was refluxed for 23 hy. The mixture was the cooled to room temperature, a $10 \%$ aqueous $\mathrm{NH}_{4} \mathrm{Cl}$ solution $(50 \mathrm{~mL})$ was added and the resulting mixture was extracted with $\mathrm{Et}_{2} \mathrm{O}(4 \times 50 \mathrm{~mL})$. The organic extract was dried over $\mathrm{Na}_{2} \mathrm{SO}_{4}$ and concentrated. The residue was fractionally distilled to give methyl 4-pentynoate (4.69 g, $71 \%$ yield) as a colourless liquid. Bp $88{ }^{\circ} \mathrm{C} / 142$ mbar. Deaerated iodobenzene $(7.31 \mathrm{~g}, 35.83 \mathrm{mmol})$ and a deaerated solution of methyl 4-pentynoate (4.42 g, $39.43 \mathrm{mmol})$ in acetonitrile $(5 \mathrm{~mL})$ were sequentially added to a deaerated mixture of $\mathrm{PdCl}_{2}\left(\mathrm{PPh}_{3}\right)_{2}(0.50 \mathrm{~g}, 0.72 \mathrm{mmol}), \mathrm{CuI}(0.27 \mathrm{~g}, 1.43 \mathrm{mmol})$ and $\mathrm{Et}_{3} \mathrm{~N}(15 \mathrm{~mL})$. The resulting mixture was stirred under argon at room temperature for $1.5 \mathrm{~h}$, then treated with a saturated aqueous $\mathrm{NH}_{4} \mathrm{Cl}$ solution $(100 \mathrm{~mL})$ and extracted with AcOEt $(3 \times 70 \mathrm{~mL})$. The organic extract was dried over $\mathrm{Na}_{2} \mathrm{SO}_{4}$, filtered through Celite and concentrated under reduced pressure. The residue was fractionally distilled to give $3 f(3.71 \mathrm{~g}, 55 \%$ yield) as a pale yeloow liquid. Bp 87-90 ${ }^{\circ} \mathrm{C} / 0.2$ mbar. EI-MS: $\mathrm{m} / z$ (\%) $188\left(\mathrm{M}^{+}, 21\right), 173$ (29), 160 (79), 145 (23), 128 (100). IR (neat): $v$ 2237, 1741, 1491, 1439, 1364, 1200, 1169, 758, $693 \mathrm{~cm}^{-1} .{ }^{1} \mathrm{H}$ NMR $\left(600 \mathrm{MHz}, \mathrm{CDCl}_{3}\right): \delta 2.63(2$ H, m, H-2), 2.73 (2 H, m, H-3), 3.71 (3 H, s, $\mathrm{OCH}_{3}$ ), 7.26 (3 H, m, H-3', H-4', and H-5'), 7.38 ppm (2 H, m, H-2' and H-6'). ${ }^{13} \mathrm{C}$ NMR (150 MHz, $\left.\mathrm{CDCl}_{3}\right): \delta 15.3(\mathrm{C}-3), 33.4(\mathrm{C}-2), 51.7$ $\left(\mathrm{OCH}_{3}\right), 81.1$ (C-5), 87.9 (C-4), 123.5 (C-1'), 127.8 (C-4'), 128.2 (C-3' and C-5'), 131.6 (C-2' and C-6'), 172.3 ppm (C-1). Anal. Calcd. for $\mathrm{C}_{12} \mathrm{H}_{12} \mathrm{O}_{2}$ : C, 76.57; H, 6.43: Found: C, 76.49; H, 6.37. 
General Procedure for the Addition of Iodine Monochloride to Alkynes 2 and 3. To a deaerated solution of an alkyne $\mathbf{3}$ or $\mathbf{5}(5.70 \mathrm{mmol})$ in dry 1,2-dichloroethane (30 $\mathrm{mL})$ was added a $1 \mathrm{M} \mathrm{CH}_{2} \mathrm{Cl}_{2}$ solution of ICl (1) $(5.70 \mathrm{~mL}, 5.70 \mathrm{mmol})$ and the mixture was stirred in the dark under argon at room temperature until completion of the reaction. It was then poured into a cold $10 \%$ aqueous $\mathrm{NaHCO}_{3}$ solution $(50 \mathrm{~mL})$ and extracted with $\mathrm{CH}_{2} \mathrm{Cl}_{2}(3 \times 30 \mathrm{~mL})$. The organic extract was washed with a $10 \%$ aqueous $\mathrm{Na}_{2} \mathrm{~S}_{2} \mathrm{O}_{3}$ solution $(20 \mathrm{~mL})$ and water $(30 \mathrm{~mL})$, dried over $\mathrm{Na}_{2} \mathrm{SO}_{4}$, analyzed by GLC and GLC/MS, and concentrated under reduced pressure. The residue was purified by MPLC on silica gel. This procedure was used to prepare $(E)-\mathbf{5 a},(E)-\mathbf{5 c},(E)-\mathbf{5 d}$ from 2a, 2c and 2d, respectively, and to synthesize $(E)-7 \mathbf{a}-\mathbf{e}$ from 3a-e. A similar procedure was employed to prepare $(E)-5 \mathbf{b}$ from $\mathbf{2} \mathbf{b}$, but 1.4 equiv of $\mathrm{ICl}$ in $\mathrm{CH}_{2} \mathrm{Cl}_{2}$ solution were used. Compound $\mathbf{6}$ was prepared from 4 by a procedure similar to that used for the synthesis of compounds $(E)-\mathbf{5 a},(E)-\mathbf{5 c},(E)-\mathbf{5 d}$, and $(E)-\mathbf{7} \mathbf{a}-\mathbf{e}$, but the reaction was performed in $\mathrm{CH}_{2} \mathrm{Cl}_{2}$ solution. It is worth mentioning that GLC analysis of the crude products which derived from the addition of iodine monochloride to $\mathbf{2 b - d , ~ 3 a - e ~ a n d ~} \mathbf{3 g}$ showed that compounds $(E)-\mathbf{5 b}-\mathbf{d}$ and $(E)$ 7a-f so obtained were stereoisomerically pure. On the other hand, GLC analysis of the crude product which derived from the addition of iodine monochloride to 2 a showed that compound $(E)$ 5a so obtained was contaminated by less than $10 \%$ of the corresponding $(Z)$-stereoisomer. Finally, it should be noted that a procedure similar to that used to prepare compounds $(E)-\mathbf{5}$ and (E)-7 was employed to prepare compound $\mathbf{1 0}$ from $\mathbf{3 f}$, but in this last case the reaction was performed at $0{ }^{\circ} \mathrm{C}$.

(E)-3-Chloro-2-iodo-2-buten-1-ol [ $(\boldsymbol{E})-5 \mathrm{a}]$. The crude product, which was obtained by reaction of 2-butyn-1-ol (2a) with 1 at room temperature for $1.5 \mathrm{~h}$, was purified by MPLC on silica gel with a mixture of petroleum ether and $\mathrm{Et}_{2} \mathrm{O}(80: 20)$ as eluent to give $(E)-5 \mathbf{a}$ as an orange liquid in $75 \%$ yield. EI-MS: $m / z(\%) 232\left(\mathrm{M}^{+}, 13\right), 127$ (8), 105 (18), 69 (19), 41 (100). IR (neat): v 3301, $1624,1427,1376,1231,1081,1017,929,678 \mathrm{~cm}^{-1} .{ }^{1} \mathrm{H}$ NMR $\left(600 \mathrm{MHz}, \mathrm{CDCl}_{3}\right): \delta 2.41(3 \mathrm{H}, \mathrm{s}$, $\mathrm{H}-4), 4.45 \mathrm{ppm}(2 \mathrm{H}, \mathrm{s}, \mathrm{H}-2) .{ }^{13} \mathrm{C} \mathrm{NMR}\left(150 \mathrm{MHz}, \mathrm{CDCl}_{3}\right): \delta 30.6$ (C-4), 67.8 (C-1), $99.4(\mathrm{C}-2)$, 129.7 ppm (C-3). Anal. Calcd. for $\mathrm{C}_{4} \mathrm{H}_{6} \mathrm{IO}: \mathrm{C}, 20.67$; H, 2.60. Found: C, 20.61; H, 2.49 .

Methyl $[(\boldsymbol{E})$-3-chloro-2-iodobut-2-enyloxy]acetate $[(\boldsymbol{E})$-5b]. The crude product, which was obtained by reaction of $\mathbf{2 b}$ with $\mathbf{1}$ at room temperature for $23 \mathrm{~h}$, was purified by MPLC on silica gel with a mixture of hexane and $\mathrm{Et}_{2} \mathrm{O}(65: 35)$ as eluent to give $(E)-\mathbf{5 b}$ as an orange liquid in 41 $\%$ yield. EI-MS: $m / z$ (\%) 269 (1), 231 (55), 215 (83), 177 (100), 119 (45). IR (neat): v 1755, 1624, 1437, 1378, 1284, 1213, 1137, 1041, $679 \mathrm{~cm}^{-1} .{ }^{1} \mathrm{H}$ NMR (600 MHz, $\left.\mathrm{CDCl}_{3}\right): \delta 2.44$ (3 H, s, H-4'), $3.77\left(3 \mathrm{H}, \mathrm{s}, \mathrm{OCH}_{3}\right), 4.09(2 \mathrm{H}, \mathrm{s}, \mathrm{H}-2), 4.50 \mathrm{ppm}\left(2 \mathrm{H}, \mathrm{s}, \mathrm{H}-1^{\prime}\right) .{ }^{13} \mathrm{C}$ NMR $\left(150 \mathrm{MHz}, \mathrm{CDCl}_{3}\right): \delta$ 30.9 (C-4'), $52.0\left(\mathrm{OCH}_{3}\right), 66.5$ (C-2), 74.8 (C-1'), 94.5 (C-2'), 132.3 (C-3'), 170.3 ppm (C-1). Anal. Calcd. for $\mathrm{C}_{7} \mathrm{H}_{10} \mathrm{ClIO}_{3}$ : C, 27.61; H, 3.31: Found: C, 27.53; H, 3.19.

Methyl $(E)(1-b u t y l-3-c h l o r o-2-i o d o h e p t-2-e n y l o x y) a c e t a t e ~[(E)-5 c]$. The crude product, which was obtained by reaction of $2 \mathrm{c}$ with 1 at room temperature for $6 \mathrm{~h}$, was purified by MPLC on silica gel with a mixture of petroleum ether and $\mathrm{Et}_{2} \mathrm{O}(95: 5)$ as eluent to give $(E)-\mathbf{5 c}$ as an orange liquid in $58 \%$ yield. EI-MS: $m / z$ (\%) 345 (18), 275 (23), 107 (14), 93 (25), 41 (100). IR (neat): $v$ $1758,1608,1437,1378,1284,1208,1120,733,685 \mathrm{~cm}^{-1} .{ }^{1} \mathrm{H}$ NMR $\left(600 \mathrm{MHz}, \mathrm{CDCl}_{3}\right): \delta 0.89(3$ H, t, $J=7.2 \mathrm{~Hz}, \mathrm{H}-1^{\prime}$ '), 0.94 (3 H, t, $J=7.4$ Hz, H-11'), 1.24 (1 H, m, H-3'), 1.34 (2 H, m, H-2'), 1.34 (1 H, m, H-3'), 1.36 (2 H, m, H-10'), 1.51 (1 H, m, H-4'), 1.57 (2 H, m, H-9'), 1.70 (1 H, m, H-4'), 2.73 (2 H, m, H-8'), 3.74 (3 H, s, $\left.\mathrm{OCH}_{3}\right), 3.83$ (1 H, m, H-2), 4.05 (1 H, m, H-2), 4.13 ppm $\left(1 \mathrm{H}, \mathrm{t}, J=6.8 \mathrm{~Hz}, \mathrm{H}-5^{\prime}\right) .{ }^{13} \mathrm{C}$ NMR $\left(150 \mathrm{MHz}, \mathrm{CDCl}_{3}\right): \delta 13.9\left(\mathrm{C}-11^{\prime}\right), 14.0\left(\mathrm{C}-1^{\prime}\right), 21.8\left(\mathrm{C}-10^{\prime}\right)$, 22.5 (C-2'), 26.6 (C-3'), 29.1 (C-9'), 34.9 (C-4'), 43.1 (C-8'), $51.8\left(\mathrm{OCH}_{3}\right), 65.0$ (C-2), $79.6(\mathrm{C}-$ 5'), 105.4 (C-6'), 135.8 (C-7'), 170.5 ppm (C-1). Anal. Calcd. for $\mathrm{C}_{14} \mathrm{H}_{24} \mathrm{ClIO}_{2}$ : C, 43.48; H, 6.26. Found: C, 53.39; H, 6.20. 


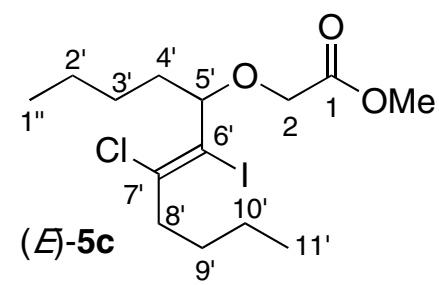

(E)-7-Chloro-6-iodoundec-6-en-5-ol $[(\boldsymbol{E})-5 \mathbf{d}]$. The crude product, which was obtained by reaction of $\mathbf{2 d}$ with 1 at room temperature for $2.5 \mathrm{~h}$, was purified by MPLC on silica gel with a mixture of petroleum ether and $\mathrm{Et}_{2} \mathrm{O}(90: 10)$ as eluent to give $(E)-5 \mathbf{d}$ as an orange liquid in $65 \%$ yield. EI-MS: $m / z$ (\%) $330\left(\mathrm{M}^{+}, 5\right), 273$ (83), 110 (22), 81 (26), 41 (100). IR (neat): v 3359, 1612, 1464, 1379, 1108, 1031, 959, 732, $687 \mathrm{~cm}^{-1} .{ }^{1} \mathrm{H}$ NMR $\left(600 \mathrm{MHz}, \mathrm{CDCl}_{3}\right): \delta 0.90(3 \mathrm{H}, \mathrm{t}, J=7.0$ Hz, H-1), 0.94 (3 H, t, J = 7.5 Hz, H-11), 1.23 (1 H, m, H-3), 1.33 (1 H, m, H-3), 1.34 (2 H, m, H2), 1.36 (2 H, m, H-10), 1.50 (1 H, m, H-4), 1.55 (1 H, m, H-4), 1.56 (2 H, m, H-9), 2.69 (2 H, m, $\mathrm{H}-8), 4.22 \mathrm{ppm}(1 \mathrm{H}, \mathrm{t}, J=6.9 \mathrm{~Hz}, \mathrm{H}-5) .{ }^{13} \mathrm{C} \mathrm{NMR}\left(150 \mathrm{MHz}, \mathrm{CDCl}_{3}\right): \delta 13.9(\mathrm{C}-11), 14.0(\mathrm{C}-1)$, 21.8 (C-10), 22.5 (C-2), 27.0 (C-3), 29.0 (C-9), 36.8 (C-4), 42.9 (C-8), 72.3 (C-5), 109.4 (C-6), 132.3 ppm (C-7). Anal. Cacd. for $\mathrm{C}_{11} \mathrm{H}_{20}$ ClIO: C, 39.96; H, 6.10. Found: C, 39.85; H, 5.98

(E)-2-Chloro-3-iodoprop-2-en-1-ol $[(\boldsymbol{E})$-6]. The crude product, which was obtained by reaction of 4 with 1 at $0{ }^{\circ} \mathrm{C}$ for $0.5 \mathrm{~h}$, was purified by MPLC on silica gel with a mixture of $\mathrm{CH}_{2} \mathrm{Cl}_{2}$ and petroleum ether $(70: 30)$ as eluent to give $(E)-6$ as an orange liquid in $46 \%$ yield. EI-MS: $\mathrm{m} / z(\%)$ 218 ( $\left.\mathrm{M}^{+}, 77\right), 183$ (100), 153 (13), 127 (95), 91 (90). IR (neat): v 3295, 1600, 1443, 1219, 1052, $1025,967,790,671 \mathrm{~cm}^{-1} .{ }^{1} \mathrm{H}$ NMR $\left(600 \mathrm{MHz}, \mathrm{CDCl}_{3}\right): \delta 4.46(2 \mathrm{H}, \mathrm{s}, \mathrm{H}-1), 6.52 \mathrm{ppm}(1 \mathrm{H}, \mathrm{s}, \mathrm{H}-$ 3). ${ }^{13} \mathrm{C} \mathrm{NMR}\left(150 \mathrm{MHz}, \mathrm{CDCl}_{3}\right): \delta 66.1(\mathrm{C}-1), 74.1(\mathrm{C}-3), 136.0 \mathrm{ppm}(\mathrm{C}-2)$. Anal. Calcd. for $\mathrm{C}_{3} \mathrm{H}_{4}$ ClIO: $\mathrm{C}, 16.50 ; \mathrm{H}, 1.85$. Found: $\mathrm{C}, 16.41 ; \mathrm{H}, 1.75$.

(E)-1-Chloro-2-iodo-1-phenylhept-1-en-3-ol [ $(\boldsymbol{E})$-7a]. The crude product, which was obtained by reaction of 3a with 1 at room temperature for $3 \mathrm{~h}$, was purified by MPLC on silica gel with a mixture of petroleum ether and $\mathrm{Et}_{2} \mathrm{O}(80: 20)$ as eluent to give $(Z)-7 \mathbf{a}$ as a pale yellow solid in 70 $\%$ yield. Mp 62-64 ${ }^{\circ} \mathrm{C}$. EI-MS: $m / z$ (\%) $350\left(\mathrm{M}^{+}, 4\right), 223$ (25), 131 (49), 102 (82), 41 (100). IR $(\mathrm{KBr}): v 3396,1623,1592,1460,1129,1061,970,862,653 \mathrm{~cm}^{-1} .{ }^{1} \mathrm{H}$ NMR $\left(600 \mathrm{MHz}, \mathrm{CDCl}_{3}\right): \delta$ 0.96 (3 H, t, $J=7.0 \mathrm{~Hz}, \mathrm{H}-7), 1.42$ (2 H, m, H-6), 1.47 (2 H, m, H-5), 1.67 (2 H, m, H-4), 4.37 (1 $\mathrm{H}, \mathrm{t}, J=6.9 \mathrm{~Hz}, \mathrm{H}-2), 7.34$ (2 H, m, H-2' and H-6'), 7.38 (1 H, m, H-4'), 7.40 ppm (2 H, m, H-3' and H.-5'). ${ }^{13} \mathrm{C}$ NMR (150 MHz, $\mathrm{CDCl}_{3}$ ): $\delta 14.1(\mathrm{C}-7), 22.6(\mathrm{C}-6), 27.1(\mathrm{C}-5), 36.9(\mathrm{C}-4), 72.6$ (C-3), 111.6 (C-2), 128.4 (C-5' and C-3'), 128.6 (C-1), 129.0(C-2' and C-6'), 129.1 (C-4'), 141.4 ppm (C-1'). Anal. Calcd. for $\mathrm{C}_{13} \mathrm{H}_{16} \mathrm{ClIO}$ : C, 44.53; H, 4.60: Found: C, 44.45; H, 4.52.

Methyl $(E)$ (1-butyl-3-chloro-2-iodo-3-phenylprop-2-enyloxy)acetate $[(E)-7 b]$. The crude product, which was obtained by reaction of $\mathbf{3 b}$ with $\mathbf{1}$ at room temperature for $4 \mathrm{~h}$, was purified by MPLC on silica gel with a mixture of hexane and $\mathrm{Et}_{2} \mathrm{O}(90: 10)$ as eluent to give $(E)-7 \mathbf{b}$ as a yellow solid in $83 \%$ yield. Mp 42-44 ${ }^{\circ} \mathrm{C}$. EI-MS: $m / z$ (\%) 333 (3), 295 (20), 277 (34), 275 (100), 163 (23). IR (KBr): v 1756, 1591, 1443, 1377, 1282, 1209, 1122, 768, $707 \mathrm{~cm}^{-1} .{ }^{1} \mathrm{H}$ NMR (600 $\left.\mathrm{MHz}, \mathrm{CDCl}_{3}\right): \delta 0.96(3 \mathrm{H}, \mathrm{t}, J=7.1 \mathrm{~Hz}, \mathrm{H}-7$ '), $1.41(1 \mathrm{H}, \mathrm{m}, \mathrm{H}-5$ '), $1.42(2 \mathrm{H}, \mathrm{q}, J=7.1 \mathrm{~Hz}, \mathrm{H}-$ 6'), 1.50 (1 H, m, H-5'), 1.67 (1 H, m, H-4'), 1.83 (1 H, m, H-4'), 3.79 (3 H, s, OCH $), 4.01$ (1 H, m, H-2), 4.19 (1 H, m, H-2), 4.30 (1 H, t, $J=6.8 \mathrm{~Hz}, \mathrm{H}-3$ '), 7.34 (2 H, m, H-2” and H-6"), 7.38 (1 H, m, H-4"), 7.41 ppm (2 H, m, H-3" and H-5"). ${ }^{13} \mathrm{C}$ NMR (150 MHz, CDCl 3 ): $\delta 14.0(\mathrm{C}-7$ '), 22.6 (C-6’), 26.8 (C-5'), 35.1 (C-4'), $51.9\left(\mathrm{OCH}_{3}\right), 65.4$ (C-2), 79.9 (C-3'), 107.7 (C-2'), 128.4 (C-3”' and C-5"), 128.9 (C-2" and C-6”), 129.2 (C-4”), 132.0 (C-1'), 141.4 (C-1”), 170.4 ppm (C-1). Anal. Calcd. For $\mathrm{C}_{16} \mathrm{H}_{20} \mathrm{IO}_{2}$ : C, 47.25; H, 4.96: Found: C, 47.12; H, 4.83. 


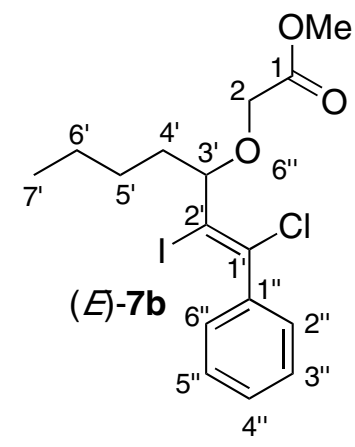

Methyl $(\boldsymbol{E})(6-c h l o r o-5-i o d o-6-p h e n y l h e x-5-e n o a t e ~[(E)-7 c]$. The crude product, which was obtained by reaction of $\mathbf{3 c}$ with $\mathbf{1}$ at room temperature for $7 \mathrm{~h}$, was purified by MPLC on silica gel with a mixture of hexane and $\mathrm{Et}_{2} \mathrm{O}(96: 4)$ as eluent to give $(E)-7 \mathbf{c}$ as a red liquid in $75 \%$ yield. EI-MS: m/z (\%) 237 (66), 205 (31), 177 (42), 141 (100), 115 (85). ${ }^{1} \mathrm{H}$ NMR (600 MHz, $\mathrm{CDCl}_{3}$ ): $\delta$ $2.00(2 \mathrm{H}, \mathrm{dt}, J=7.5$ and $7.3 \mathrm{~Hz}, \mathrm{H}-3), 2.45(2 \mathrm{H}, \mathrm{t}, J=7.5 \mathrm{~Hz}, \mathrm{H}-2), 2.91(2 \mathrm{H}, \mathrm{t}, J=7.3 \mathrm{~Hz}, \mathrm{H}-$ 4), $3.71\left(3 \mathrm{H}, \mathrm{s}, \mathrm{OCH}_{3}\right), 7.34$ (2 H, m, H-2' and H-6'), 7.37 (1 H, m, H-4'), 7.38 ppm (2 H, m, H3 ' and $\mathrm{H}-5$ '). ${ }^{13} \mathrm{C}$ NMR (150 MHz, $\left.\mathrm{CDCl}_{3}\right): \delta 23.7(\mathrm{C}-3), 32.5(\mathrm{C}-2), 41.3(\mathrm{C}-4), 51.7\left(\mathrm{OCH}_{3}\right)$, 99.7 (C-5), 128.4 (C-3' and C-5'), 128.9 (C-4'), 129.1 (C-2' and C-6'), 129.4 (C-6), 141.8 (C-1'), 173.5 ppm (C-1). Anal. Calcd. for $\mathrm{C}_{13} \mathrm{H}_{14} \mathrm{ClIO}_{2}$ : C, 42.82; H, 3.87. Found: C, 42.75; H, 3.79.

$(\boldsymbol{E})$-1-Chloro-2-iodo-1-phenyloct-1-ene $[(\boldsymbol{E})-7 \mathbf{d}]$. The crude product, which was obtained by reaction of 3d with 1 at room temperature for $2 \mathrm{~h}$, was purified by MPLC on silica gel with hexane as eluent to give (Z)-7d as a pale yellow liquid in $93 \%$ yield. EI-MS: $m / z(\%) 348\left(\mathrm{M}^{+}\right.$, 13), 185 (8), 151 (47), 125 (21), 115 (100). IR (neat): v 1594, 1488, 1443, 1377, 1121, 1029, 875, $769 \mathrm{~cm}^{-1} .{ }^{1} \mathrm{H}$ NMR $\left(600 \mathrm{MHz}, \mathrm{CDCl}_{3}\right): \delta 0.93(3 \mathrm{H}, \mathrm{t}, J=6.9 \mathrm{~Hz}, \mathrm{H}-1), 1.36(2 \mathrm{H}, \mathrm{m}, \mathrm{H}-3), 1.37$ (2 H, m, H-2), 1.42 (2 H, m, H-4), 1.65 (2 H, m, H-5), 2.84 (2 H, m, H-6), 7.34 (1 H, m, H-4'), 7.35 (2 H, m, H-2' and H-6'), 7.38 ppm (2 H, m, H-3' and H-5'). $\left.{ }^{13} \mathrm{C} \mathrm{NMR} \mathrm{(150} \mathrm{MHz}, \mathrm{CDCl}_{3}\right): \delta$ 14.0 (C-1), 22.6 (C-2), 28.1 (C-4), 28.4 (C-5), 31.6 (C-3), 42.1 (C-6), 101.6 (C-7), 128.2 (C-8), 128.3 (C-3' and C-5'), 128.8 (C-4'), 129.2 (C-2' and C-6'), 142.1 ppm (C-1'). Anal. Calcd. for $\mathrm{C}_{14} \mathrm{H}_{18} \mathrm{ClI}: \mathrm{C}, 48.23$; H, 5.20. Found: C, 48.13; H, 5.09.

$(E)$-1-(1-Butyl-3-chloro-2-iodo-3-phenylprop-2-enyloxy)butane $[(E)-7 e]$. The crude product, which was obtained by reaction of 3e with 1 at room temperature for $1 \mathrm{~h}$, was purified by MPLC on silica gel with a mixture of hexane and $\mathrm{Et}_{2} \mathrm{O}(99: 1)$ as eluent to give $(E)$-7e as a pale yellow liquid in $74 \%$ yield. EI-MS: $m / z$ (\%) $406\left(\mathrm{M}^{+}, 2\right), 349$ (67), 293 (100), 275 (14), 131 (58). IR (neat): $v 1618,1592,1465,1444,1330,1123,1097,709,693 \mathrm{~cm}^{-1} .{ }^{1} \mathrm{H} \mathrm{NMR}\left(600 \mathrm{MHz}, \mathrm{CDCl}_{3}\right): \delta$ 0.94 (3 H, t, $J=7.1 \mathrm{~Hz}, \mathrm{H}-7), 0.96$ (3 H, t, $J=7.4 \mathrm{~Hz}, \mathrm{H}-4$ '), 1.38 (1 H, m, H-5), 1.39 (2 H, m, H6), 1.46 (2 H, m, H-3'), 1.47 (1 H, m, H-5), 1.60 (1 H, m, H-4), 1.63 (2 H, m, H-2'), 1.71 (1 H, m, H-4), 3.33 (1 H, m, H-1'), 3.53 (1 H, m, H-1'), 4.04 (1 H, t, J = 6.8 Hz, H-3), 7.34 (2 H, m, H-2” and H-6"), 7.38 (1 H, m, H-4"), 7.39 ppm (2 H, m, H-3" and H-5"). ${ }^{13} \mathrm{C} \mathrm{NMR} \mathrm{(150} \mathrm{MHz,} \mathrm{CDCl} 3$ ):

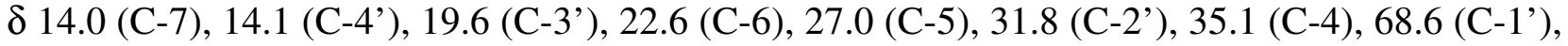
79.5 (C-3), 110.6 (C-2), 128.4 (C-3" and C-5”), 128.99 (C-4”), 129.04 (C-2” and C-6”), 130.1 (C1), 141.71 ppm (C-1"). Anal. Calcd. for $\mathrm{C}_{17} \mathrm{H}_{24}$ ClIO: C, 50.20; H, 5.95. Found: C, 50.09; H, 5.82.

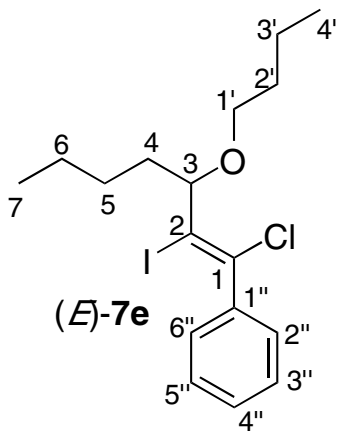


(E)-1-Chloro-2-iodo-1-phenylprop-1-ene $[(\boldsymbol{E})-7 \mathbf{f}]$. The crude product, which was obtained by reaction of 1-phenyl-1-propyne (3g) with 1 at room temperature for $2 \mathrm{~h}$, was purified by MPLC on silica gel with petroleum ether as eluent to give $(E)$-7f as a pale yellow liquid in $77 \%$ yield. EIMS: $m / z(\%) 278\left(\mathrm{M}^{+}, 82\right), 151(11), 115$ (100), 89 (12), 63 (7). ${ }^{1} \mathrm{H}$ NMR (200 MHz, $\left.\mathrm{CDCl}_{3}\right): \delta$ $2.74\left(3 \mathrm{H}, \mathrm{s}, \mathrm{CH}_{3}\right), 7.36$ ppm $\left(5 \mathrm{H}, \mathrm{m}, \mathrm{C}_{6} \mathrm{H}_{5}\right.$. Anal. Calcd. for $\mathrm{C}_{8} \mathrm{H}_{8} \mathrm{ClI}: \mathrm{C}, 38.81 ; \mathrm{H}, 2.89$. Found: C, 38.77; H, 2.69 .

5-Iodo-6-phenyl-3,4-dihydro-2H-pyran-2-one (9). The crude product, which was obtained by reaction of $3 f$ with 1 at $0{ }^{\circ} \mathrm{C}$ for $3 \mathrm{~h}$, was purified by MPLC on silica gel with a mixture of hexane and $\mathrm{Et}_{2} \mathrm{O}(80: 20)$ as eluent to give 9 as a pale yellow solid in $41 \%$ yield. Mp $32-34{ }^{\circ} \mathrm{C}$. EI-MS: m/z $300\left(\mathrm{M}^{+}, 51\right), 258$ (11), 173 (25), 127 (10), 105 (100). IR (neat): v 1775, 1695, 1675, 1596, 1449, 1288, 1194, 1072, $691 \mathrm{~cm}^{-1} .{ }^{1} \mathrm{H}$ NMR (600 MHz, CDCl $): \delta 2.79(2 \mathrm{H}, \mathrm{m}, \mathrm{H}-3), 2.97(2 \mathrm{H}$, m, H-4), 7.39 (1 H, m, H-4'), 7.40 (2 H, m, H-3' and H-5'), 7.57 ppm (2 H, m, H-2' and H-6'). ${ }^{13} \mathrm{C}$ NMR (150 MHz, $\mathrm{CDCl}_{3}$ ): $\delta 30.2$ (C-3), 34.4 (C-4), 70.0 (C-5), 128.1 (C-3' and C-5'), 129.3 (C-2' and C-6'), 129.7 (C-4'), 134.4 (C-1'), 150.6 (C-6), 167.3 ppm (C-2). Anal. Calcd. for $\mathrm{C}_{11} \mathrm{H}_{9} \mathrm{IO}_{2}$ : C, 44.03; H, 3.02. Found: C, 43.94; H, 2.97.

Table 1. ${ }^{13} \mathrm{C}$ Chemical shifts of the Acetylenic Carbon Atoms of some Alkyl Substituted Acetylenes and Propargyl Alcohol 2a-d

$$
\text { Alkyl- } \stackrel{\alpha}{\mathrm{C}} \equiv \underset{\mathrm{C}}{\boldsymbol{\beta}} \stackrel{\stackrel{\mathrm{O}}{\mathrm{O}}-\mathrm{R}^{1}}{\mathrm{R}}
$$

2a-d, 4

\begin{tabular}{cccccccc}
\hline \multicolumn{3}{c}{ Compound } & & $\delta_{\alpha}$ & $\delta_{\beta}$ & $\Delta \delta_{(\mathrm{C} \equiv \mathrm{C})}$ & Ref. \\
\cline { 1 - 4 } & $\mathrm{Alkyl}$ & $\mathrm{R}$ & $\mathrm{R}^{1}$ & & & & a \\
\cline { 1 - 4 } $\mathbf{4}$ & $\mathrm{H}$ & $\mathrm{H}$ & $\mathrm{OH}$ & 74.4 & 82.5 & -8.1 & a \\
$\mathbf{2 a}$ & $\mathrm{Me}$ & $\mathrm{H}$ & $\mathrm{OH}$ & 81.6 & 78.5 & +3.1 & This work \\
$\mathbf{2}$ & $\mathrm{Me}$ & $\mathrm{H}$ & $\mathrm{CH}_{2} \mathrm{COOMe}$ & 83.8 & 73.8 & +10.0 & This work \\
$\mathbf{2 d}$ & $n-\mathrm{Bu}$ & $n-\mathrm{Bu}$ & $\mathrm{CH}_{2} \mathrm{COOMe}$ & 87.4 & 78.0 & +9.4 & This work \\
\hline
\end{tabular}

a) Camps, F.; Coll, J.; Moretò, J. M.; Torras, J. J. Org. Chem. 1989, 54, 1969.

Table 2. ${ }^{13} \mathrm{C}$ Chemical shifts of the Acetylenic Carbon Atoms of some Phenyl Substituted Acetylenes 3a-e

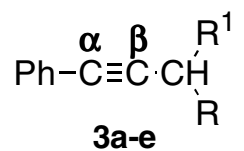

\begin{tabular}{cccccc}
\hline \multicolumn{2}{c}{ Compound } & $\delta_{\alpha}$ & $\delta_{\beta}$ & $\Delta \delta_{(\mathrm{C} \equiv \mathrm{C})}$ \\
\cline { 1 - 3 } & $\mathrm{R}$ & $\mathrm{R}^{1}$ & & & \\
\hline 3a & $n-\mathrm{Bu}$ & $\mathrm{OH}$ & 84.7 & 90.3 & -5.6 \\
3b & $n-\mathrm{Bu}$ & $\mathrm{OCH}_{2} \mathrm{COOMe}$ & 86.6 & 87.0 & -0.4 \\
3c & $\mathrm{H}$ & $\mathrm{CH}_{2} \mathrm{CH}_{2} \mathrm{COOMe}$ & 81.5 & 88.8 & -7.3 \\
3d & $\mathrm{H}$ & $n-\mathrm{C}_{5} \mathrm{H}_{11}$ & 80.6 & 90.4 & -9.8 \\
3e & $n-\mathrm{Bu}$ & $\mathrm{O}-n-\mathrm{Bu}$ & 85.2 & 89.0 & -3.8 \\
\hline
\end{tabular}


Table 3. ${ }^{13} \mathrm{C}$ Chemical shifts of the Olefinic Carbon Atoms of Chloroiodoalkenes
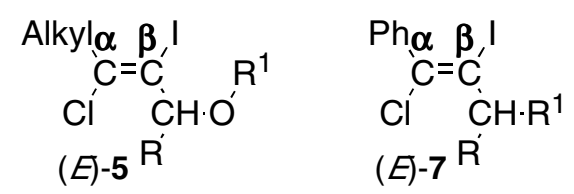

\begin{tabular}{ccc}
\hline Compound & $\delta_{\alpha}$ & $\delta_{\beta}$ \\
\hline$(E)-\mathbf{5 a}$ & 129.8 & 99.4 \\
$(E)-\mathbf{5 b}$ & 132.3 & 94.5 \\
$(E)-\mathbf{5 c}$ & 135.8 & 105.4 \\
$(E)-\mathbf{5 d}$ & 132.3 & 109.4 \\
$(E)-\mathbf{7 a}$ & 128.6 & 111.6 \\
$(E)-\mathbf{7 b}$ & 132.0 & 107.7 \\
$(E)-\mathbf{7} \mathbf{c}$ & 129.4 & 99.7 \\
$(E)-\mathbf{7 d}$ & 128.2 & 101.6 \\
$(E)-\mathbf{7}$ & 130.1 & 110.6 \\
\hline
\end{tabular}

\section{References}

1) Braun, S.; Kalinowski, H. -O.; Berger, S. 150 and more basic NMR experiments - A practical course, Wiley-VCH Publishers, 1998.

2) Coles, Y.; Cazes, B.; Gore, J. Bull. Soc. Chim. France 1987, 165.

3) Bourelle-Wargnier, F. B.; Vincent, M.; Chuche, J. J. Org. Chem. 1980, 45, 428.

4) White, J. D.; Jensen, M. S. J. Am. Chem. Soc. 1995, 117, 6224.

5) Kabalka, G. W.; Wang, L.; Pagni, R. M. Tetrahedron 2001, 57, 8017. 